\title{
Using Chemical and Physical Mutagens for Induction of Genetic Variation in the Quantitative and Qualitative Traits of Three Cultivars of Faba beans (Vicia faba L.)
}

\author{
Laith Mohammed Jawad Al-Shamma \\ Department of Biology, College of Science, University of Baghdad, Baghdad-Iraq. \\ E-mail: dr.prof1976@yahoo.com.
}

\begin{abstract}
Filed experiment was conducted to evaluate the role of chemical and physical mutagens in inducing genetic variation in the quantitative and qualitative traits, such as morphological characteristics, yield components, seed yield and protein yield of three cultivars Zaina, Aguadulce and local of Faba beans (Vicia faba L.). Nitrous acid mutagen was prepared. This acid was unstable, weakly acidic compound and decomposes rapidly that has been prepared immediately in the form of cold according to the chemical methods. Also electric shocks were used according to the physical methods, seeds were sown in the season of 2010-2011 at Research field of Biology Dept., College of Science, Baghdad Univ. Factorial Experiment was arranged in a Randomized Complete Block Design (RCBD) with three replicates. At maturity, seeds were collected first season of treatments, including the treatment comparison and then sown in the secound season of 2011-2012. Results showed that treatment of seeds soaked in nitrous acid mutagen solution for $24 \mathrm{hrs}$ gave the highest seeds yield in both seasons recording 4370.39 and $3255.01 \mathrm{~kg} / \mathrm{ha}$, respectively and not significantly differed at 12-hrs soaking in the second season. Soaking treatment for 24 hrs was superior in some phenotypic traits such as plant height, leaf area index and yield components (number of branches/plant, number pods in plant, number of seeds in pod and the rate of seed weight). Also superiority in protein yield was found in the first season reached $857.87 \mathrm{~kg} / \mathrm{ha}$. The highest percentage of protein was found after using electric shock treatment for 6 or 3 min which differed significantly from seeds soaked in nitrous acid, Aguadulce and local cultivars gave higher protein percentages than Zaina cultivar in both seasons. Zaina cultivar showed superiority in seeds and protein yield in the first season reached 3774.61 and $734.4 \mathrm{~kg} / \mathrm{ha}$, respectively. While local cultivar gave the highest seeds and protein yield in the second season 3073.57 and $635.19 \mathrm{~kg} / \mathrm{ha}$, respectively. A significant interaction between cultivars and treatments was found, Zaina cultivar was superior in seeds and protein yield in the first season reaching 4997.09 and $929.94 \mathrm{~kg} / \mathrm{ha}$ respectively and seed yield $3982.79 \mathrm{~kg} /$ ha in the second season when soaked for $12 \mathrm{hrs}$. Local cultivar gave the highest value of protein yield with mean value $755.71 \mathrm{~kg} / \mathrm{ha}$, and did not differ significantly with 3 min shocks and soaked for $24 \mathrm{hrs}$ in the second season. It is concluded from this study that soaking seeds in nitrous acid mutagen solution for $24 \mathrm{hrs}$ was effective in inducting genetic variation in faba bean cultivars which is useful in breeding programs either by selection or crosses.
\end{abstract}

Keywords: Nitrous acid mutagen, Electric Shock (ES), Faba bean cultivars.

\section{Introduction}

Faba beans (Vicia faba L.) are a good source of dietary minerals, such as phosphorus, potassium, calcium, sulphur and iron. Calcium content ranges from 120 to 260 $\mathrm{mg} / 100 \mathrm{~g}$ dry mass, its seed not only provide a cheap source of protein but also food of high nutritive value especially in the diet of low income people, it is a good alternative to expensive meat and fish protein [1]. In small concentrations, nitrous acid can be beneficial to most plants as a fertilizer, combined with other elements to form nitrates [2], implicated in the modulation of several physiological and developmental processes in plant [3], and plant resistance to pathogens [4]. Nitrous acid is a weak and an unstable acid, it molecular formula was (HONO). Nitrous acid can decomposed in solution in two ways [5]. In first way, it produces nitrogen 
dioxide, nitric oxide and water as follows, 2HONO------ $\mathrm{NO}_{2}+\mathrm{NO}+\mathrm{H}_{2} \mathrm{O}$. In a second pathway, it may decompose to nitric acid, nitrous oxide, and water, as follows, $4 \mathrm{HONO}------2 \mathrm{HNO}_{3}+\mathrm{N}_{2} \mathrm{O}+\mathrm{H}_{2} \mathrm{O}$. Nitrous acid has been shown to deaminate nucleobases in vivo in DNA, and investigated the pathway of reverse mutations induced with nitrous acid in Saccharomyces cerevisiae, mutation frequencies induced with nitrous acid [6]. Bancroft et al. [7] showed that nitrous acid has also been used to produce mutants of plant viruses e.g. cowpea chlorotic mottal virus. All the mutations studied found that nitrous acid have involved changes in the coat protein amino acid sequence [8]. Hor and Noor [9] soaked seeds of four local cultivars of rice (Oryza sativa L.) in $0.1,0.3$, and $0.5 \mathrm{M}$ nitric acid for $0,3,6,12,18$, and $24 \mathrm{hrs}$, their results showed that germination was significantly affected by nitric acid concentration and soaking duration. Sakugawa and Cape [10] studied the effects of atmospheric nitrous acid on the physiological of pine trees, they found that exposure to HONO over 2 months affects photosynthesis and nutrient status of pine trees, by an increasing in the carbon to nitrogen ratio $(\mathrm{C} / \mathrm{N})$. In earlier studies, the regulatory roles of $\mathrm{NO}$ have been reported at different stages of crop development and have been especially found beneficial in promoting seed germination and seedling stage of most plant species [11]. Nitrite oxide (NO) is a signaling molecule in a variety of physiological processes during plant growth and development, and also is an important modulator of disease resistance [12]. Pharmacological studies using mammalian nitric oxide syntheses (NOS) inhibitors along with biochemical and indirect genetic studies have suggested that plants also synthesize NO using an arginine-dependent enzyme similar to mammalian NO [13, 14 and 15]. High voltage and current used in the process of shock [16]. This method has encouraged some researchers to test the effect of the difference in voltage on the seed and this cause variations in soybean [17] as well as in wheat and barley [18]. Also some researchers, used an electric current to enter the parts DNA with in protoplast cell [19], as well as to stimulate the germination of some seeds [20]. Mentioned by Jugenheimer
[21] it can cause genetic mutations in plants exposed pollen or seeds or fetuses small to physical or chemical, such as types of radiation, heat, electricity and mustard gas, among others. The results showed significant effect on the growth parameters (leaf long and breadth) and nutritive value of the plants by stimulation of plant growth by means of electric shock application [22]. Elsahookie [17] results showed that electric shock (until M5) reduced plant height of the lines S7A and S5B by 61.1 and $74.2 \mathrm{~cm}$., respectively. On the contrary, seed yields (ton/ha) for same lines soybeans were increased by $33.5 \%$ and $64 \%$, respectively. Results showed that electric shock used on wheat and barley seed gave significant variation in several traits, such as plant height, tillers $/ \mathrm{m}^{2}$, seed weight, number of seeds/ spikes, grain yield and protein percentage by different varieties, generations and shock periods [16]. Elsahookie and Elsubahi [23] Found that different genotypes gave different responses to periods of ES, indicating that one period of ES can not be recommended for all genotypes to induce variations through the use of electric shock to open a power supply 220 AC for periods 2, 4 and $6 \mathrm{~min}$. The studies that dealt with mutagen nitrous acid of this crop were not enough. The purpose of this study was to investigate know the role of nitrous acid and electric shock in inducing genetic variation and study their effects on morphological traits, protein percentage, yield components and seed yield .

\section{Materials and Methods \\ Plant Materials:}

Three cultivars of Faba bean (Vicia faba L.) were used in this study, namely Zaina (Italian origin), Aguadulce (France origin) and Local (Production of Iraq). All cultivars were obtained from Department of Field Crops Science- Agreculture College Baghhdad University.

\section{Nitrous Acid preparation:}

The acid was an unstable, weakly acidic compound and decomposes rapidly, therefore it has been prepared immediately in the form of cold. It include tow mixture, the first was prepared by adding $600 \mathrm{ml}$ of $\mathrm{HCl}$ slowly to $600 \mathrm{ml}$ of distilled water, in ice bath to get mix, its volume of $1200 \mathrm{ml}$, and the second 
Journal of Al-Nahrain University

Science

mixture prepare by diluting $160 \mathrm{~g}$ of Sodium nitrite $\mathrm{NaNO}_{2}$ with $400 \mathrm{ml}$ of distilled water. Then first mixture was added to the second mixture in ice bath, to get nitrous acid solution asfollwing equation: $\mathrm{HCl}+\mathrm{NaNO}_{2}$------ $\mathrm{HNO}_{2}+\mathrm{NaCl}$. Seeds were soaked in nitrous acid for 12 and $24 \mathrm{hrs}$ and kept in ice bath [ 24 ].

\section{Electric Shock Treatment:}

Choose 600 seeds were germinated inside cheese cloth even phase out the radical length of 2-5 mm, then seedling soaked in aqueous solution (1\% sodium chloride) for three hrs., so that the salt enters the plant tissue to facilitate the delivery of electrical current into the cells, and transferred to a glass vessel in which the same solution and connected by two electric poles AC 220 volt power source where it was put inside the seedling aluminum perforated paper with the weight of iron to make them dipped in the solution. Electric current to open the period 3 and 6 minutes on the different samples were treated seedlings. After completing the process of shock transferred the seedling vessel in running water for three hours to expel the salt.

\section{Layout of the Experimint:}

The experiment was conducted in a clay loan soil. Seedling of treatments and control (untreated) were planted in the filed during winter 2010-2011 at 24 October, in the Experimental Station of the Biology Dep. College of Sciences, University of Baghdad. Factorial experiment was arranged in randomized Complete Block Design (RCBD) with three replicates. The area of experimental unit was $10 \mathrm{~m}^{2}$ contain five lines, the space between lines were $0.70 \mathrm{~m}$ and between plants $0.30 \mathrm{~m}$. The superphosphate fertilizes (P2O5 $45 \%$ ) at a rate of $80 \mathrm{~kg} / \mathrm{ha}$ was added to the soil before seedling sowing [25], and urea fertilizer $\mathrm{N} 46 \%$ at rate of $50 \mathrm{~kg} / \mathrm{ha}$, was applied before the first irrigation in a form of urea [26]. The other required culture practices for growing faba bean were followed as recommended. After harvesting seeds were collected and sowing in the second season 2011-2012 and in the same way that has been cultivated in the first season.

\section{Studied Parameter:}

The following parameters were studied during the growth period of faba bean: days from planting to $50 \%$ flowering, plant height $(\mathrm{cm})$, leaf area index (L.A.I), number of branches/plant, number of pods/plant, number of seeds/pod, seed weight, seed yield ( $\mathrm{kg} / \mathrm{ha})$, protein percentage and protein yield $(\mathrm{kg} / \mathrm{ha})$.

\section{Statistical Analysis:}

Obtained data were subjected to the proper analysis of variance of Randomized Complete Block Design (RCBD). The treatment means were compared at $0.05 \%$ level of significant using Least Significant Differences test (L.S.D.).

\section{Results and Discussion}

Plants obtained from electric shock for a period of 6,3 minutes and control treatment were earlier $50 \%$ in flowering compared with plants obtained from seeds soaked in nitrous acid mutagen in the first season were 81.88 , 82.11 and 82.55 days, respectively. While in the second season early flowering was shown in plants, treated with electric shock for a period of 3 min compared with the another treatment was 74.27 days may be due to the group of genes affected and reaction responsible for the character early by electric shock. Zaina cultivar was early flowering from others were 76.66 and 83.95 days for two seasons, respectively. Interaction between cultivars and treatments revealed that Zaina cultivar with seed soaked in nitrous acid for $24 \mathrm{hrs}$ flowering earlier was 73.66 days in the first season, and 67.5 days at electric shock for a period 3 minutes in the second season (Table (1)). 
Table (1)

Mean number of days from planting to 50\% flowering, higher values represent season 2010-2011 and the lower values represent season 2011-2012.

\begin{tabular}{|c|c|c|c|c|c|c|}
\hline $\begin{array}{l}\text { Treatment } \\
\text { cultivars }\end{array}$ & $\begin{array}{l}\text { Soaked in } \\
\text { nitrous acid } \\
\text { for } 12 \text { hrs }\end{array}$ & $\begin{array}{c}\text { Soaked in } \\
\text { nitrous acid } \\
\text { for } 24 \text { hrs }\end{array}$ & $\begin{array}{c}\text { Electric } \\
\text { shock for } 3 \\
\text { min }\end{array}$ & $\begin{array}{c}\text { Electric } \\
\text { shock for } 6 \\
\text { min }\end{array}$ & Control & Mean \\
\hline Zaina & $\begin{array}{c}75.66 \\
99 \\
\end{array}$ & $\begin{array}{c}73.66 \\
90 \\
\end{array}$ & $\begin{array}{c}81 \\
67.5 \\
\end{array}$ & $\begin{array}{l}76.33 \\
79.33 \\
\end{array}$ & $\begin{array}{l}80 \\
79\end{array}$ & $\begin{array}{l}77.33 \\
82.96 \\
\end{array}$ \\
\hline Aguadulce & $\begin{array}{c}92.66 \\
101 \\
\end{array}$ & $\begin{array}{c}93.01 \\
98 \\
\end{array}$ & $\begin{array}{l}80 \\
79\end{array}$ & $\begin{array}{c}82.66 \\
81\end{array}$ & $\begin{array}{l}83.66 \\
80.33 \\
\end{array}$ & $\begin{array}{l}86.39 \\
87.86 \\
\end{array}$ \\
\hline Local & $\begin{array}{c}90.33 \\
100\end{array}$ & $\begin{array}{c}91.33 \\
92\end{array}$ & $\begin{array}{l}85.33 \\
76.33\end{array}$ & $\begin{array}{c}86.66 \\
79\end{array}$ & $\begin{array}{c}84 \\
85.33\end{array}$ & $\begin{array}{l}87.53 \\
86.53\end{array}$ \\
\hline Mean & $\begin{array}{c}86.21 \\
100 \\
\end{array}$ & $\begin{array}{l}86.03 \\
93.33 \\
\end{array}$ & $\begin{array}{l}82.11 \\
74.27 \\
\end{array}$ & $\begin{array}{l}81.88 \\
79.77 \\
\end{array}$ & $\begin{array}{l}82.55 \\
81.55 \\
\end{array}$ & \\
\hline L.S.D0.05 & $\begin{array}{l}(V)=1.25 \\
(V)=0.87\end{array}$ & $\begin{array}{l}(T)=1.61 \\
(T)=1.13\end{array}$ & $\begin{array}{l}(V * T)=2.80 \\
(V * T)=1.96\end{array}$ & & & \\
\hline
\end{tabular}

Results presented in Table (2) showed that the highest plant height was $94 \mathrm{~cm}$ in the first season, when soaked in nitrous acid for $24 \mathrm{hrs}$ reached. This increase in plant height could be justified on the basis that the Nitrous acid contain a nitric oxide $\mathrm{NO}$ that act as a bioactive molecule and involved in many physiological processes in plants, such as growth and development of plant tissue by operating the auxin signals transduction, The primary physiological effect of auxin in plants is to stimulate the elongation of cells in shoot, and support the growth of stem [27 and 28], but in the second season electro-shock treatment for a period of $3 \mathrm{~min}$ gave the highest height reached to $66.83 \mathrm{~cm}$. Results indicated that local cultivar gave maximum plant height rate $84.72 \mathrm{~cm}$, while in the second season Aguadulce cultivar was the superior and gave plant height $60 \mathrm{~cm}$.The variation in plant height among varieties may be corresponded with phenotypic difference as a result of different genotypes [29]. Also shows a significant interaction between cultivars and treatments, Zaina cultivar gave the highest value of plant height $100.1 \mathrm{~cm}$ when soaked in nitrous acid for $24 \mathrm{hrs}$ in the first season. While Aguadulce cultivar gave the highest value75 $\mathrm{cm}$ when treated with electric shock for $3 \mathrm{~min}$ in the second season.

Table (2)

Mean plant height (cm), higher values represent season 2010-2011 and the lower values represent season 2011-2012.

\begin{tabular}{|c|c|c|c|c|c|c|}
\hline Treatment & $\begin{array}{c}\text { Soaked in } \\
\text { nitrous } \\
\text { acid for } 12 \\
\text { hrs } \\
\end{array}$ & $\begin{array}{c}\text { Soaked in } \\
\text { nitrous } \\
\text { acid for } 24 \\
\text { hrs } \\
\end{array}$ & $\begin{array}{c}\text { Electric } \\
\text { shock for } \\
3 \text { min }\end{array}$ & $\begin{array}{l}\text { Electric } \\
\text { shock for } \\
6 \text { min }\end{array}$ & Control & Mean \\
\hline Zaina & $\begin{array}{c}89.5 \\
49\end{array}$ & $\begin{array}{c}100.1 \\
48\end{array}$ & $\begin{array}{l}67 \\
61\end{array}$ & $\begin{array}{l}68 \\
57\end{array}$ & $\begin{array}{l}67 \\
50\end{array}$ & $\begin{array}{c}78.32 \\
53\end{array}$ \\
\hline Aguadulce & $\begin{array}{l}84 \\
47\end{array}$ & $\begin{array}{c}82.3 \\
54\end{array}$ & $\begin{array}{c}80.7 \\
75\end{array}$ & $\begin{array}{c}74.8 \\
65\end{array}$ & $\begin{array}{l}73 \\
59\end{array}$ & $\begin{array}{c}78.96 \\
60\end{array}$ \\
\hline Local & $\begin{array}{c}96.5 \\
51 \\
\end{array}$ & $\begin{array}{l}99.6 \\
57.5 \\
\end{array}$ & $\begin{array}{l}83.5 \\
64.5 \\
\end{array}$ & $\begin{array}{c}73 \\
58.6 \\
\end{array}$ & $\begin{array}{l}71 \\
55 \\
\end{array}$ & $\begin{array}{l}\mathbf{8 4 . 7 2} \\
\mathbf{5 7 . 3 2} \\
\end{array}$ \\
\hline Mean & $\begin{array}{l}90 \\
49 \\
\end{array}$ & $\begin{array}{c}94 \\
53.16\end{array}$ & $\begin{array}{l}77.06 \\
66.83 \\
\end{array}$ & $\begin{array}{c}71.93 \\
60.2 \\
\end{array}$ & $\begin{array}{l}70.33 \\
54.66 \\
\end{array}$ & \\
\hline L.S.D0.05 & $\begin{array}{l}(V)=1.23 \\
(V)=1.13\end{array}$ & $\begin{array}{l}(T)=1.59 \\
(T)=1.46\end{array}$ & $\begin{array}{l}\left(V^{*} \mathbf{T}\right)=2.75 \\
\left(V^{*} \mathbf{T}\right)=2.53\end{array}$ & & & \\
\hline
\end{tabular}


Journal of Al-Nahrain University Science

Leaf area index was affected significantly by different treatments (Table (3)). The highest leaf area index was obtained when seeds soaked in nitrous acid for $24 \mathrm{hrs}$ were 2.52 and 2.21 for two seasons, respectively. The reason for this increase might be due to that Nitric oxide molecule, which can affect the amount of radiation intercepted by plant, and thus crop productivity, by promoting leaf expansion and simulative influence on cell and cell division [30]. Increase of leaf area index is essential because it determines the rate of plant photosynthesis, capacity expansion that resulting an increase of seeds yield. Increasing leaf area index does not consider only increasing the ability of a plant to capture light, but also changing its growth and maintenance process [31]. There is no significant difference between the cultivars in the first season. While each of the local and Zaina cultivars showed the highest rate were 1.93 and $1.89 \mathrm{~cm}^{2}$ in the second season. Results shows a significant interaction between cultivars and treatments, Zaina gave highest value of leaf area index when soaked in nitrous acid for $24 \mathrm{hrs}$ was 2.91 in the first season. While Aguadulce cultivars gave the highest was 2.42 in the second season.

Table (3)

Mean leaf area index, higher values represent season 2010-2011 and the lower values

represent season 2011-2012.

\begin{tabular}{|c|c|c|c|c|c|c|}
\hline cultivars & $\begin{array}{c}\text { Soaked in } \\
\text { nitrous } \\
\text { acid for } 12 \\
\text { hrs } \\
\end{array}$ & $\begin{array}{c}\text { Soaked in } \\
\text { nitrous } \\
\text { acid for } 24 \\
\text { hrs } \\
\end{array}$ & $\begin{array}{c}\text { Electric } \\
\text { shock for } \\
3 \text { min }\end{array}$ & $\begin{array}{c}\text { Electric } \\
\text { shock for } \\
6 \text { min }\end{array}$ & Control & Mean \\
\hline Zaina & $\begin{array}{c}2.1 \\
1.85\end{array}$ & $\begin{array}{l}2.91 \\
1.89\end{array}$ & $\begin{array}{l}1.47 \\
1.91\end{array}$ & $\begin{array}{c}1.71 \\
1.9\end{array}$ & $\begin{array}{c}1.5 \\
1.92\end{array}$ & $\begin{array}{l}1.93 \\
1.89\end{array}$ \\
\hline Aguadulce & $\begin{array}{c}2.1 \\
1.38 \\
\end{array}$ & $\begin{array}{l}2.25 \\
2.42 \\
\end{array}$ & $\begin{array}{l}1.75 \\
1.12 \\
\end{array}$ & $\begin{array}{l}1.71 \\
2.01 \\
\end{array}$ & $\begin{array}{c}1.9 \\
2\end{array}$ & $\begin{array}{l}1.94 \\
1.78 \\
\end{array}$ \\
\hline Local & $\begin{array}{c}2 \\
2.24\end{array}$ & $\begin{array}{c}2.4 \\
2.33\end{array}$ & $\begin{array}{l}1.9 \\
1.5\end{array}$ & $\begin{array}{c}1.67 \\
2.1\end{array}$ & $\begin{array}{l}1.35 \\
1.5\end{array}$ & $\begin{array}{l}1.86 \\
1.93\end{array}$ \\
\hline Mean & $\begin{array}{l}2.06 \\
1.82 \\
\end{array}$ & $\begin{array}{l}2.52 \\
2.21 \\
\end{array}$ & $\begin{array}{c}1.7 \\
1.51 \\
\end{array}$ & $\begin{array}{c}1.69 \\
2 \\
\end{array}$ & $\begin{array}{c}1.58 \\
1.8\end{array}$ & \\
\hline L.S.D0.05 & $\begin{array}{c}(\mathrm{V})=\mathbf{n . s} \\
(\mathrm{V})=\mathbf{0 . 0 7}\end{array}$ & $\begin{array}{l}(T)=0.16 \\
(T)=0.09\end{array}$ & $\begin{array}{l}(\mathbf{V} * \mathbf{T})=0.28 \\
(\mathbf{V} * \mathbf{T})=\mathbf{0 . 1 6}\end{array}$ & & & \\
\hline
\end{tabular}

Table (4) explained that seeds soaked in nitrous acid for $24 \mathrm{hrs}$ gave the highest number of branches / plant were 11.03 and 13.66 in both seasons, and did not differ significantly with electro-shock treatment for $3 \mathrm{~min}$ in the second season. Local cultivar was marked significantly by giving the highest number of branches per plant in the second season was 12.68 branches. Local cultivar gave the highest number of branches per plant when soaked in nitrous acid for $24 \mathrm{hrs}$ were 12.4 and 17 branches in both seasons and did not differ significantly with Zaina cultivar in the first season. 
Table (4)

Mean number of branches/plant, higher values represent season 2010-2011 and the lower values represent season 2011-2012.

\begin{tabular}{|c|c|c|c|c|c|c|}
\hline cultivars & $\begin{array}{c}\text { Soaked in } \\
\text { nitrous acid } \\
\text { for } 12 \text { hrs } \\
\end{array}$ & $\begin{array}{c}\text { Soaked in } \\
\text { nitrous acid } \\
\text { for } 24 \mathrm{hrs} \\
\end{array}$ & $\begin{array}{c}\text { Electric } \\
\text { shock for } 3 \\
\text { min } \\
\end{array}$ & $\begin{array}{c}\text { Electric } \\
\text { shock for } 6 \\
\text { min } \\
\end{array}$ & Control & Mean \\
\hline Zaina & $\begin{array}{l}9.2 \\
9.5 \\
\end{array}$ & $\begin{array}{l}12.2 \\
10.5\end{array}$ & $\begin{array}{c}6.6 \\
11.4 \\
\end{array}$ & $\begin{array}{c}6.3 \\
12.2 \\
\end{array}$ & $\begin{array}{c}7 \\
9.3 \\
\end{array}$ & $\begin{array}{c}8.26 \\
10.58 \\
\end{array}$ \\
\hline Aguadulce & $\begin{array}{c}8.8 \\
9\end{array}$ & $\begin{array}{c}8.5 \\
13.5\end{array}$ & $\begin{array}{c}5.3 \\
14.9\end{array}$ & $\begin{array}{c}6 \\
10.8\end{array}$ & $\begin{array}{l}5.3 \\
8.5\end{array}$ & \begin{tabular}{|c|}
6.78 \\
11.34
\end{tabular} \\
\hline Local & $\begin{array}{c}11.88 \\
8.5 \\
\end{array}$ & $\begin{array}{c}12.4 \\
17 \\
\end{array}$ & $\begin{array}{l}5.66 \\
14.5 \\
\end{array}$ & $\begin{array}{c}5.33 \\
13 \\
\end{array}$ & $\begin{array}{c}6.1 \\
10.4 \\
\end{array}$ & $\begin{array}{c}8.27 \\
12.68\end{array}$ \\
\hline Mean & $\begin{array}{c}9.96 \\
9\end{array}$ & $\begin{array}{l}11.03 \\
13.66\end{array}$ & \begin{tabular}{|l|}
5.85 \\
13.6
\end{tabular} & $\begin{array}{c}5.87 \\
12\end{array}$ & $\begin{array}{c}6.13 \\
9.4\end{array}$ & \\
\hline L.S.D0.05 & $\begin{array}{l}(\mathrm{V})=\mathbf{n . s} \\
(\mathrm{V})=\mathbf{0 . 0 7}\end{array}$ & $\begin{array}{l}(T)=0.16 \\
(T)=0.09\end{array}$ & $\begin{array}{l}\left(V^{*} \mathbf{T}\right)=0.28 \\
\left(\mathbf{V}^{*} \mathbf{T}\right)=\mathbf{0 . 1 6}\end{array}$ & & & \\
\hline
\end{tabular}

Distinction treatment of soaked in nitrous acid for $24 \mathrm{hrs}$ gave the highest number of pods/plant in both seasons were 27.23 and 18.2 pods and did not differ significantly with soaked in nitrous acid for $12 \mathrm{hrs}$ in the first season. This increase in pods number may be due to nitric oxide, NO controls the floral induction, and production floral buds [3], also NO operates the auxin signals transduction, auxin caused reduction in the flower abscission percentage and then production the highest number of pods setting [32]. As superiority Zaina cultivar gave the highest number was 24.44 and 14.22 pods in both seasons respectively, and did not differ significantly with local cultivar. The highest number of pods per plant were gave by Zaina cultivar when soaked in nitrous acid for $24 \mathrm{hrs}$ were 28.5 and 16.5 pods in both seasons and did not differ significantly with local cultivar when soaked in nitrous acid for $12 \mathrm{hrs}$ in the first season (Table (5)).

Table (5)

Mean number of pod/plant, higher values represent season 2010-2011 and the lower values represent season 2011-2012.

\begin{tabular}{|c|c|c|c|c|c|c|}
\hline cultivars & $\begin{array}{c}\text { Soaked in } \\
\text { nitrous acid } \\
\text { for } 12 \text { hrs } \\
\end{array}$ & $\begin{array}{c}\text { Soaked in } \\
\text { nitrous acid } \\
\text { for } 24 \text { hrs } \\
\end{array}$ & $\begin{array}{c}\text { Electric } \\
\text { shock for } 3 \\
\text { min } \\
\end{array}$ & $\begin{array}{c}\text { Electric } \\
\text { shock for } 6 \\
\text { min } \\
\end{array}$ & Control & Mean \\
\hline Zaina & $\begin{array}{c}26.5 \\
14 \\
\end{array}$ & $\begin{array}{l}28.5 \\
16.5 \\
\end{array}$ & $\begin{array}{c}21.3 \\
14 \\
\end{array}$ & $\begin{array}{c}23.91 \\
14.6\end{array}$ & $\begin{array}{l}22 \\
12 \\
\end{array}$ & $\begin{array}{l}24.44 \\
14.22 \\
\end{array}$ \\
\hline Aguadulce & $\begin{array}{c}24.8 \\
13\end{array}$ & $\begin{array}{c}24.2 \\
15\end{array}$ & \begin{tabular}{|l|}
14.6 \\
13.3
\end{tabular} & $\begin{array}{c}16 \\
10.7\end{array}$ & $\begin{array}{c}18.5 \\
13\end{array}$ & $\begin{array}{c}19.62 \\
13\end{array}$ \\
\hline Local & $\begin{array}{c}30 \\
15.5 \\
\end{array}$ & $\begin{array}{c}29 \\
15.2 \\
\end{array}$ & $\begin{array}{l}16.9 \\
15.5 \\
\end{array}$ & $\begin{array}{l}15.6 \\
15.1 \\
\end{array}$ & $\begin{array}{l}26.7 \\
12.2 \\
\end{array}$ & $\begin{array}{c}23.64 \\
14.7 \\
\end{array}$ \\
\hline Mean & $\begin{array}{c}27.1 \\
14.16\end{array}$ & $\begin{array}{c}27.23 \\
18.2\end{array}$ & $\begin{array}{c}17.6 \\
14.26\end{array}$ & $\begin{array}{c}18.5 \\
13.46\end{array}$ & $\begin{array}{l}22.4 \\
12.4\end{array}$ & \\
\hline L.S.D0.05 & $\begin{array}{l}(V)=1.05 \\
(V)=0.87\end{array}$ & $\begin{array}{l}(T)=1.36 \\
(T)=1.12\end{array}$ & $\begin{array}{l}\left(V^{*} T\right)=2.36 \\
(V * T)=1.95\end{array}$ & & & \\
\hline
\end{tabular}

No significant difference between the cultivars and treatments were showed in the first season. While in second season the highest number of seeds per pods were obtained when soaked in nitrous acid for 12 and 24 hours were 3.35 and 3.14 seed, respectively (Table (6)). Local cultivar gave the highest number was 3.16 seed. A significant interaction between cultivars and treatment was found Zaina cultivar when soaked in nitrous acid for $12 \mathrm{hrs}$ gave highest number of seed reached to 5 seeds/pod. 
Table (6)

Mean number of seed/pod, higher values represent season 2010-2011 and the lower values represent season 2011-2012.

\begin{tabular}{|c|c|c|c|c|c|c|}
\hline cultivars & $\begin{array}{l}\text { Soaked in } \\
\text { nitrous acid } \\
\text { for } 12 \text { hrs }\end{array}$ & $\begin{array}{l}\text { Soaked in } \\
\text { nitrous acid } \\
\text { for } 24 \text { hrs }\end{array}$ & $\begin{array}{c}\text { Electric } \\
\text { shock for } 3 \\
\text { min }\end{array}$ & $\begin{array}{c}\text { Electric } \\
\text { shock for } 6 \\
\text { min }\end{array}$ & Control & Mean \\
\hline Zaina & $\begin{array}{l}3.0 \\
5.0\end{array}$ & $\begin{array}{c}2.9 \\
2.85\end{array}$ & $\begin{array}{l}3.95 \\
1.82\end{array}$ & $\begin{array}{l}3.6 \\
2.5 \\
\end{array}$ & $\begin{array}{l}3.2 \\
3.6 \\
\end{array}$ & $\begin{array}{l}3.33 \\
3.16 \\
\end{array}$ \\
\hline Aguadulce & $\begin{array}{l}3.3 \\
2.55\end{array}$ & $\begin{array}{c}3.2 \\
3.23\end{array}$ & $\begin{array}{l}3.8 \\
2.9\end{array}$ & $\begin{array}{l}4.2 \\
1.9\end{array}$ & $\begin{array}{l}2.9 \\
2.3\end{array}$ & $\begin{array}{l}3.48 \\
2.57\end{array}$ \\
\hline Local & $\begin{array}{l}3.5 \\
2.5 \\
\end{array}$ & $\begin{array}{c}3.6 \\
3.36\end{array}$ & $\begin{array}{l}3.1 \\
2.6\end{array}$ & $\begin{array}{l}3.1 \\
2.9 \\
\end{array}$ & $\begin{array}{c}3 \\
2.4\end{array}$ & $\begin{array}{l}3.26 \\
2.75\end{array}$ \\
\hline Mean & $\begin{array}{l}3.26 \\
3.35\end{array}$ & \begin{tabular}{|l|}
3.23 \\
3.14
\end{tabular} & \begin{tabular}{|l|}
3.61 \\
2.44
\end{tabular} & $\begin{array}{l}3.36 \\
2.43\end{array}$ & $\begin{array}{l}3.03 \\
2.76\end{array}$ & \\
\hline L.S.D0.05 & $\begin{array}{l}(\mathrm{V})=\mathrm{n.s} \\
(\mathrm{V})=\mathbf{0 . 3 0}\end{array}$ & $\begin{array}{l}(T)=n . s \\
(T)=0.39\end{array}$ & $\begin{array}{l}\left(V^{*} \mathbf{T}\right)=\mathbf{n . s} \\
\left(V^{*} T\right)=\mathbf{0 . 6 8}\end{array}$ & & & \\
\hline
\end{tabular}

The electric shock treatment for 3 min gave the highest average of seed weight was $1.53 \mathrm{~g}$ in the first season, While in the second season soaked in nitrous acid for $24 \mathrm{hrs}$ gave 1.21 g. Zaina cultivar gave the highest average of seed weight was $1.49 \mathrm{~g}$ in the first season only. Local cultivar when soaked in nitrous acid for $24 \mathrm{hrs}$ gave the highest average seed weight was $1.47 \mathrm{~g}$ in the second season only (Table (7)).

Table (7)

Mean seed weight (g), higher values represent season 2010-2011 and the lower values represent season 2011-2012.

\begin{tabular}{|c|c|c|c|c|c|c|}
\hline $\begin{array}{l}\text { Treatment } \\
\text { cultivars }\end{array}$ & $\begin{array}{l}\text { Soaked in } \\
\text { nitrous acid } \\
\text { for } 12 \text { hrs }\end{array}$ & $\begin{array}{c}\text { Soaked in } \\
\text { nitrous acid } \\
\text { for } 24 \text { hrs }\end{array}$ & $\begin{array}{c}\text { Electric } \\
\text { shock for } 3 \\
\text { min } \\
\end{array}$ & $\begin{array}{c}\text { Electric } \\
\text { shock for } \\
6 \text { min } \\
\end{array}$ & Control & Mean \\
\hline Zaina & $\begin{array}{l}1.25 \\
1.24\end{array}$ & $\begin{array}{l}1.73 \\
1.04\end{array}$ & $\begin{array}{c}1.59 \\
1.0\end{array}$ & $\begin{array}{c}1.49 \\
1.1\end{array}$ & $\begin{array}{l}1.4 \\
1.2 \\
\end{array}$ & $\begin{array}{l}1.49 \\
1.11\end{array}$ \\
\hline Aguadulce & $\begin{array}{l}1.3 \\
1.1\end{array}$ & $\begin{array}{l}1.31 \\
1.14\end{array}$ & $\begin{array}{l}1.52 \\
1.06\end{array}$ & $\begin{array}{l}1.03 \\
1.16\end{array}$ & $\begin{array}{c}1.3 \\
1.15\end{array}$ & $\begin{array}{l}1.29 \\
1.12\end{array}$ \\
\hline Local & $\begin{array}{l}1.05 \\
1.17\end{array}$ & $\begin{array}{l}1.15 \\
1.47\end{array}$ & $\begin{array}{c}1.5 \\
0.99\end{array}$ & $\begin{array}{c}1.3 \\
1.25\end{array}$ & $\begin{array}{l}1.21 \\
1.09\end{array}$ & $\begin{array}{l}1.24 \\
1.19\end{array}$ \\
\hline Mean & $\begin{array}{c}1.2 \\
1.17\end{array}$ & $\begin{array}{l}1.39 \\
1.21\end{array}$ & $\begin{array}{l}1.53 \\
1.01\end{array}$ & $\begin{array}{l}1.27 \\
1.17\end{array}$ & $\begin{array}{l}1.3 \\
1.14\end{array}$ & \\
\hline L.S.D0.05 & $\begin{array}{c}(V)=0.12 \\
(V)=\text { n.s }\end{array}$ & $\begin{array}{l}(T)=0.16 \\
(T)=0.09\end{array}$ & $\begin{array}{l}\left(V^{*} \mathbf{T}\right)=\mathbf{n . s} \\
\left(V^{*} \mathbf{T}\right)=\mathbf{0 . 1 6}\end{array}$ & & & \\
\hline
\end{tabular}

The effect of treatments on seeds yield are shown in Table8. Seeds soaked in nitrous acid for $24 \mathrm{hrs}$ had a significant effect on seeds yield as it gave the highest seed yield in both seasons were 4370.39 and $3255.01 \mathrm{~kg} / \mathrm{ha}$, respectively, due to superiority in yield components (Tables 4,5.6 and7) and did not differ significantly with treatment of soaking in nitrous acid for $12 \mathrm{hrs}$ in the second season was $3214.33(\mathrm{~kg} / \mathrm{ha})$. Zaina cultivar gave the highest seed yield in the first season was $3774.61 \mathrm{~kg} / \mathrm{ha}$, due to superiority in yield components (Tables (4, 5, 6 and 7)). Local cultivar gave the highest seed yield was $3073.75(\mathrm{~kg} / \mathrm{ha})$ in the second season. Zaina cultivar with soaked in nitrous acid for $24 \mathrm{hrs}$ gave highest seed yield was 4997.09 (kg/ha) in the first season and with soaked in nitrous acid for $12 \mathrm{hrs}$ in the second season was 3982.79(kg/ha). 
Table (8)

Mean seed yield (kg/ha), higher values represent season 2010-2011 and the lower values represent season 2011-2012.

\begin{tabular}{|c|c|c|c|c|c|c|}
\hline cultivars & $\begin{array}{c}\text { Soaked in } \\
\text { nitrous acid } \\
\text { for } 12 \text { hrs } \\
\end{array}$ & $\begin{array}{c}\text { Soaked in } \\
\text { nitrous acid } \\
\text { for } 24 \text { hrs } \\
\end{array}$ & $\begin{array}{l}\text { Electric shock } \\
\quad \text { for } 3 \text { min }\end{array}$ & $\begin{array}{c}\text { Electric } \\
\text { shock for } \\
6 \text { min } \\
\end{array}$ & Control & Mean \\
\hline Zaina & $\begin{array}{l}4000.02 \\
3982.79\end{array}$ & $\begin{array}{l}4997.09 \\
3001.01\end{array}$ & $\begin{array}{l}3323.51 \\
1991.02\end{array}$ & $\begin{array}{l}3436.06 \\
2954.52\end{array}$ & $\begin{array}{l}3116.37 \\
2213.14\end{array}$ & $\begin{array}{l}3374.61 \\
2828.49\end{array}$ \\
\hline Aguadulce & $\begin{array}{l}4250.03 \\
2762.56 \\
\end{array}$ & $\begin{array}{l}4111.12 \\
2997.99 \\
\end{array}$ & $\begin{array}{l}2460.41 \\
3100.83 \\
\end{array}$ & $\begin{array}{l}2101.32 \\
1811.57 \\
\end{array}$ & $\begin{array}{l}2550.31 \\
2169.95 \\
\end{array}$ & $\begin{array}{l}3094.63 \\
2568.58 \\
\end{array}$ \\
\hline Local & $\begin{array}{l}4187.26 \\
2897.66\end{array}$ & $\begin{array}{l}4002.97 \\
3766.03\end{array}$ & $\begin{array}{c}2757.1 \\
3185.61\end{array}$ & $\begin{array}{l}2013.99 \\
3331.88\end{array}$ & $\begin{array}{l}3091.64 \\
2187.57\end{array}$ & $\begin{array}{l}3210.59 \\
3073.75\end{array}$ \\
\hline Mean & $\begin{array}{l}4145.77 \\
3214.33\end{array}$ & $\begin{array}{l}4370.39 \\
3255.01\end{array}$ & $\begin{array}{l}2847.00 \\
2759.15\end{array}$ & $\begin{array}{l}2517.12 \\
2699.32\end{array}$ & $\begin{array}{l}2919.44 \\
2190.22\end{array}$ & \\
\hline L.S.D0.05 & $\begin{array}{l}(V)=151.40 \\
(V)=180.34\end{array}$ & $\begin{array}{l}(T)=195.46 \\
(T)=232.81\end{array}$ & $\begin{array}{l}\left(V^{*} \mathbf{T}\right)=338.55 \\
\left(V^{*} \mathbf{T}\right)=403.25\end{array}$ & & & \\
\hline
\end{tabular}

Electric shock showed positive variations in quantitative inheritance for this trait. Table (9) indicates that the electric shock treatment for a period of 3 and 6 minutes gave the highest percentage of protein in both seasons were $22.5,22.83,22.66$ and $22.71 \%$, respectively. Aguadulce and local cultivars gave the highest percentage of protein in both seasons were $21.36,20.7,21.45$ and $20.52 \%$, respectively, compared with the Zaina cultivar. The highest percentage of protein gave by Aguadulce and local cultivars when electric shock for a period of $6 \mathrm{~min}$ in the first season only reached to 23.3 and $23.1 \%$.

Table (9)

Mean protein percentage, higher values represent season 2010-2011 and the lower values represent season 2011-2012.

\begin{tabular}{|c|c|c|c|c|c|c|}
\hline cultivars & $\begin{array}{l}\text { Soaked in } \\
\text { nitrous acid } \\
\text { for } 12 \text { hrs } \\
\end{array}$ & $\begin{array}{c}\text { Soaked in } \\
\text { nitrous acid } \\
\text { for } 24 \mathrm{hrs} \\
\end{array}$ & $\begin{array}{c}\text { Electric } \\
\text { shock for } 3 \\
\text { min } \\
\end{array}$ & $\begin{array}{c}\text { Electric } \\
\text { shock for } 6 \\
\text { min } \\
\end{array}$ & Control & Mean \\
\hline Zaina & $\begin{array}{c}16.66 \\
16\end{array}$ & $\begin{array}{c}18.61 \\
18.1 \\
\end{array}$ & $\begin{array}{l}22.8 \\
22.4\end{array}$ & $\begin{array}{l}21.6 \\
22.7\end{array}$ & $\begin{array}{c}18.5 \\
19\end{array}$ & $\begin{array}{l}19.63 \\
19.64 \\
\end{array}$ \\
\hline Aguadulce & $\begin{array}{l}20.13 \\
18.79\end{array}$ & $\begin{array}{l}20.89 \\
19.02\end{array}$ & $\begin{array}{c}22.5 \\
23\end{array}$ & $\begin{array}{c}23.3 \\
22.56\end{array}$ & $\begin{array}{c}20 \\
18.9\end{array}$ & $\begin{array}{l}21.36 \\
20.45\end{array}$ \\
\hline Local & $\begin{array}{l}19.59 \\
18.67 \\
\end{array}$ & $\begin{array}{l}19.62 \\
18.99 \\
\end{array}$ & $\begin{array}{l}22.2 \\
23.1 \\
\end{array}$ & $\begin{array}{c}23.1 \\
22.87 \\
\end{array}$ & $\begin{array}{c}19 \\
19.5 \\
\end{array}$ & $\begin{array}{c}20.7 \\
20.62 \\
\end{array}$ \\
\hline Mean & $\begin{array}{l}18.79 \\
17.82 \\
\end{array}$ & $\begin{array}{l}19.7 \\
18.7 \\
\end{array}$ & $\begin{array}{c}22.5 \\
22.83 \\
\end{array}$ & $\begin{array}{l}22.66 \\
22.71 \\
\end{array}$ & $\begin{array}{l}19.16 \\
19.13\end{array}$ & \\
\hline L.S.D0.05 & $\begin{array}{l}(V)=0.62 \\
(V)=0.59\end{array}$ & $\begin{array}{c}(T)=0.8 \\
(T)=0.76\end{array}$ & $\begin{array}{c}(\mathbf{V} * \mathbf{T})= \\
1.39 \\
(\mathbf{V} * \mathbf{T})=\mathbf{n . s}\end{array}$ & & & \\
\hline
\end{tabular}

That highest protein yield was $857.87(\mathrm{~kg} / \mathrm{ha})$ when seeds soaked in nitrous acid for $24 \mathrm{hrs}$ in the first season, because of its superiority in the seed yield (Table (8)). As Protein yield $(\mathrm{kg} / \mathrm{ha})$ was calculated by multiplying the protein percentage by seed yield $(\mathrm{kg} / \mathrm{ha})$. While in the second season observed treatment of soaked in nitrous acid for $12 \mathrm{hrs}$ gave lowest protein yield compared with another treatments, due to the different in protein percentage and seeds yield (Tables $(8$ and 9)). Zaina cultivar gave the highest protein yield in the first season reached to $734.4 \mathrm{~kg} / \mathrm{ha}$, due to its superiority in seed yield. Local cultivar gave the highest protein yield $687.36 \mathrm{~kg} / \mathrm{ha})$ in the second season. A significant interaction between cultivars and treatments was found, Zaina cultivar gave the highest protein yield when soaked in nitrous acid for $24 \mathrm{hrs}$ was $929.94(\mathrm{~kg} / \mathrm{ha})$ in the first season, while local cultivar at the electric shock for 6 minutes gave the highest protein 
Table (10)

Mean protein yield (kg/ha), higher values represent season 2010-2011 and the lower values represent season 2011-2012.

\begin{tabular}{|c|c|c|c|c|c|c|}
\hline $\begin{array}{l}\text { Treatment } \\
\text { cultivars }\end{array}$ & $\begin{array}{c}\text { Soaked in } \\
\text { nitrous acid } \\
\text { for } 12 \text { hrs }\end{array}$ & $\begin{array}{c}\text { Soaked in } \\
\text { nitrous acid } \\
\text { for } 24 \text { hrs }\end{array}$ & $\begin{array}{c}\text { Electric } \\
\text { shock for } 3 \\
\text { min }\end{array}$ & $\begin{array}{c}\text { Electric } \\
\text { shock for } \\
6 \text { min }\end{array}$ & Control & Mean \\
\hline Zaina & $\begin{array}{c}666.4 \\
637.66 \\
\end{array}$ & $\begin{array}{l}929.94 \\
542.61\end{array}$ & $\begin{array}{l}757.46 \\
445.76 \\
\end{array}$ & $\begin{array}{l}741.69 \\
660.67 \\
\end{array}$ & $\begin{array}{l}576.53 \\
451.58 \\
\end{array}$ & $\begin{array}{c}734.4 \\
547.71 \\
\end{array}$ \\
\hline Aguadulce & $\begin{array}{l}\mathbf{8 5 4 . 8 6} \\
518.97\end{array}$ & $\begin{array}{c}858.36 \\
570.2\end{array}$ & $\begin{array}{l}553.02 \\
712.86\end{array}$ & $\begin{array}{l}488.79 \\
408.42\end{array}$ & $\begin{array}{l}510.06 \\
409.36\end{array}$ & $\begin{array}{l}653.01 \\
523.96 \\
\end{array}$ \\
\hline Local & $\begin{array}{l}820.61 \\
542.15\end{array}$ & $\begin{array}{l}785.31 \\
715.51\end{array}$ & $\begin{array}{l}612.01 \\
736.09\end{array}$ & $\begin{array}{l}465.89 \\
755.71\end{array}$ & $\begin{array}{l}\mathbf{5 8 7 . 5 8} \\
426.51\end{array}$ & $\begin{array}{l}654.28 \\
635.19\end{array}$ \\
\hline Mean & $\begin{array}{l}780.62 \\
566.26 \\
\end{array}$ & $\begin{array}{l}857.87 \\
609.44 \\
\end{array}$ & $\begin{array}{l}640.83 \\
631.57 \\
\end{array}$ & $\begin{array}{l}565.45 \\
608.26 \\
\end{array}$ & $\begin{array}{l}558.05 \\
429.24 \\
\end{array}$ & \\
\hline L.S.D0.05 & $\begin{array}{c}(V)=37.98 \\
(V)=409.36\end{array}$ & $\begin{array}{l}(T)=44.02 \\
(T)=451.85\end{array}$ & $\begin{array}{c}(V * T)=84.92 \\
(V * T)=426.51\end{array}$ & & & \\
\hline
\end{tabular}

\section{References}

[1] Chavan, J.K.; Kute, L.S. and Kadam, S.S. "Broad bean. In: Hand book of World Food Legumes: Nutritional. Processing Technology and Utilization"; vol. 1. CRC Press, Boca Raton, pp 223-245; 1989.

[2] Considine, G.D.; "Nitric acid. Pages 24582459. In: G.D., Considine, editor. Van Nostrand's Scientific Encyclopedia"; John Wiley and Sons, Inc., New York, New York. 2002.

[3] Seligman, K.; Saviani, E.E.; Oliveira, H.C.; Pinto-Maglio, C.A.F. and Salgado, I. "Floral transition and nitric oxid emission during flower Development in Arabidopsis thaliana is affected in nitrate reductase- Deficient plants"; Plant Cell Physiology, 49(7):11121121, 2008.

[4] Palmieri, M. C.; Sell, S.; Huang, X.; Scherf, M.; Werner, T.; Durner, J. and Lindermayer, C. "Nitric oxide - responsive genes and promoters in Arabidopsis thaliana: a bioinformatics approach"; Journal of Experimental Botany, 59:177186, 2008.

[5] Greenwood, N.; and Earnshaw, A. "Chemistry of the elements ( $2^{\text {nd }}$ ed.). Oxford: Butterworth- Heinemann"; p.462, 1997.

[6] Zimmermann, F.K., Schwaier, R. and Laer, U.V. "Nitrous acid and Alkylating nitrosamides: Mutation fixation in Saccharomyces Cerevisiae. Z.Vererbungsl"; 98:152-166, 1966.
[7] Bancroft, J. B.; Mclean, G.D.; Rees, M.W. and Short, M.N. "The effect of an arginyl to a cysteinyl replacement on the uncoating behavior of a spherical plant virus"; Virology, 45:707-715, 1971.

[8] Robinson, D.J.; "Inactivation and mutagenesis of Tobacco Rattle virus by nitrous acid"; J. Gen. Virol. , 18:215-222, 1973.

[9] Hor, Y.L.; and Noor, K.H. "The effects of after- ripening, Heat and nitric oxide on seed dormancy of four Local cultivars of Padi (Oryza sativa L.)"; Pertanika, 9(1):57-63, 1986.

[10] Sakugawa, H. and Cape, J.N. "Harmful effects of atmospheric nitrous acid on the physiological status of Scots pine trees. Environmental Pollution"; 147(3):532-534, 2007.

[11] Libourel, I.G.; Bethke, P.C.; De Michele, R. and Jones, R.L. "Nitric oxide gas stimulates germination of dormant Arabidopsis seeds use Of a flow through apparatus for delivery of nitric oxide"; Planta, 223: 813-820, 2006.

[12] Bethke, P.C.; Libourel, I.G.; Aoyama, N.; Chung, Y.Y.; Still, D.W. and Jones, R.L. "The Arabidopsis aluron layer responds to nitric oxide Gibberellin, and abscisic acid and is sufficient and necessary for seed Dormancy"; Plant Physiology, 143:11731188, 2007. 
[13] Lamattina, L.; Garcia- Mata, C.; Graziano, M. and Pagnussat, G. "Nitric oxide: the versatility of an extensive signal molecule"; Annu. Rev. Plant Biol., 54:109 136, 2003.

[14] Neill, S.; Bright, J.; Desikan, R.; Hancock, J., Harrison, J.; and Wilson, I. "Nitric oxide evolution and perception"; Journal of Experimental Botany, 59:25-35, 2008.

[15] Corpas, F.J.; Palma, J.M.; Del Rio, L.A. and Barroso, J.B. "Evidence supporting the existence of L- arginine-dependent nitric oxide syntheses Activity in plants"; New Phytol., 184:9-14, 2009.

[16] Al-subahi, W. A. R. J. "Incidents and genetic variability in some field crops by electric shock"; PhD Dissertation. Field crops Department - college of Agriculture. University of Baghdad, P.P: 90, 1996.

[17] Elsahookie, M. M. "Evaluation of soybean mutants induced by electric shock"; Iraqi. J. Agric. Sci., 23 (2): 99-106, 1992.

[18] Elsahookie, M. M., and Al-subahi, W. A. R. "Induction of genetic variation in wheat and barley by electric shock"; Iraqi. J. Agric. Sci. 32(3): 139-146, 2001.

[19] Fromm. M .L. P.; Taylor, and Walbot, V. "Expression of genes lectroported in no cot and dicot plant cell"; Proc . Nat. Acad. Sci., (USA) .82: 5824- 5828, 1985.

[20] Briggs, D. E. Barley. John Wiley and Sons. Ins., N.Y., USA, PP.612; 1987.

[21] Jugenheimer, R. W. "Corn Improvement: Seed Production and Uses"; John Wiley and Sons, Inc., USA. PP: 670; 1976.

[22] Kareem, S. A. "Stimulation of plant growth by means of electric shock application"; Nig .J . Pure and Appl. Sci., Vol. 14: 855-860, 1999.

[23] Elsahookie, M. M.; Al-subahi, W. A. R. "Variation of sunflower traits induced by electric shock"; Iraqi. J. Agric. Sci., 32(5) :91 -102, 2001.

[24] Strnadova, K. "A method of preparation and Application of Nitrous acid as a mutagen in Claviceps purpurea"; Folia Microbiol., 21:455-458, 1976.

[25] Aguilera-Diaz, C.; and Recald, M. L. "Effect of plant density and inorganic nitrogen fertilizer on field bean ( Vicia faba L)" ; J. Agric. Sci., Camb., 125 (1) :87-93, 1995.
[26] Mady, M. A. "Effect of foliar application with yeast extract and Zinc on fruit setting and yield of faba bean (Vicia faba L)"; J. Biol. Chem. Environ. Sci., 4(2):109-127, 2009.

[27] Correa-Aragunde, N.; Graziano, M. and Lamattina, L. "Nitric oxide plays a central role in determining lateral root development in tomato"; Planta, 218:900-905, 2004.

[28] Jain, V.K. "Fundamentals of plant physiology"; S. Chand and Company LTD. Ramnagar, New Delhi; 2008.

[29] Hail, K.S.; and Jaafar, A.A. "Biometry and responses of faba bean varieties to black bean Aphid, Aphis faba scopdi";American- Eurasian Journal of Agriculture and Environmental Science, 2(4): 328-334, 2007.

[30] Wendehenne, D.; Pugin, A.; Klessig, D.F. and Dumer, J. "Nitric oxide: Comparative synthesis and signaling in animal and plant cell"; Trends Plant Sciences, 6:177-183, 2001.

[31] Costa, L.C.; Dennett, M.D.; and Morisson, J.I.L. "Variation in dark respiration during the growth of field bean (Vicia faba L.) under different soil water regimes and densities"; In: Monteith, J.L., Scott, R.K. and Unsworth, M.H. (eds). Resource capture by crops. Nottingham: Nottingham University Press; 1994.

[32] Hayat, S.; Hasan, S.A.; Mori, M.; Fariduddin, Q. and Ahmed, A. "Nitric oxide: Chemistry, Biosynthesis, and Physiological role"; In: Hayat, S., Mori, M., Pichtel, J. and Ahmed, A. (eds). Plant physiology. WILEY-VCH Verlag $\mathrm{GmbH} \&$ Co. KGaA, Weinheim; 2010.

الخلاصة

تفذت تجربة حقلية لمعرفة دور المطفرات الكيميائية

والفيزيائية في أحداث التغايرات الوراثية الكمية والنوعية من

خلال دراسة الصفات المورفولوجية للنبات وحاصل البذور

ومكوناته ونسبة البروتين في البذور لثلاثة أصناف من

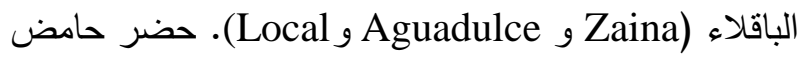

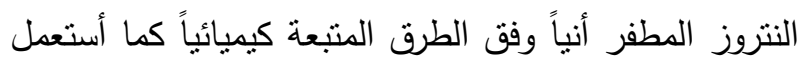

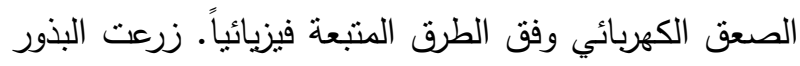

المعاملة في الحقل في الموسم 2010- 2011 في حقل 
أبحاث قسم علوم الحياة كلية العلوم/ جامعة بغداد. استخدمت

تجربة عاملية بتصميم القطاعات الكاملة المعثاة (RCBD) بثلاثة مكررات وعند النضج نت جمع بذور المعاملات بضمنها معاملة المقارنة وزرعت في الموسم التالي 2011-2012.

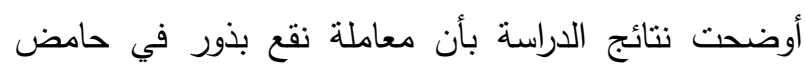

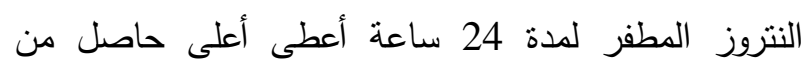

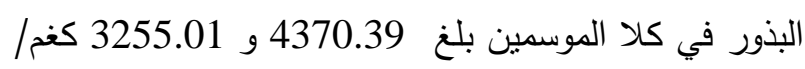
هكتار على التوالي، ولم يختلف معنوياً عن مدة النقع 12 ساعة في الموسم الثاني كما تفوقت معاملة النقع لمدة 24 ساعة في بعض الصفات المظهرية مثل ارتفاع النبات ودليل

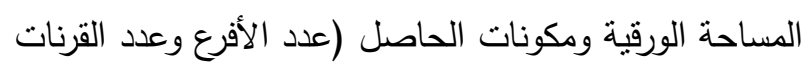

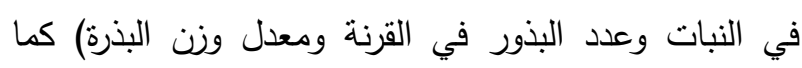
تفوقت في حاصل البروتين في الموسم الأول بلغ

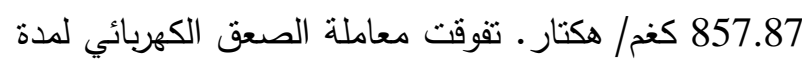

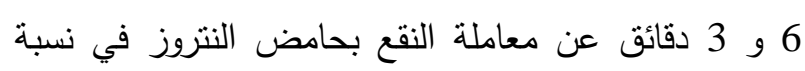

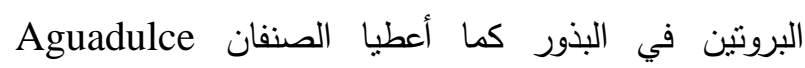
و Local نسبة بروتين أعلى من الصنف Zaina في كلا لإلفين

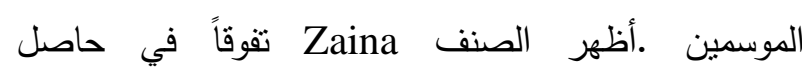

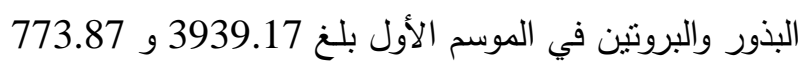

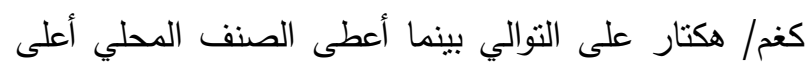
حاصل بذور وبروتين في الموسم الثاني بلغ 3295.28 و687.36 كغم/ هكتار على التوالي. ظهر تداخل معنوي بين

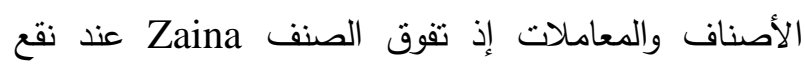

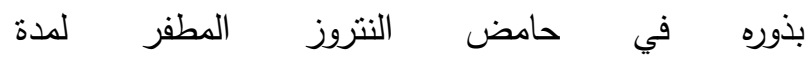
24 ساعة بحاصل البذور والبروتين في الموسم الأول بلغ 4997.09 و 929.94 كغم/ هكتار بالتتابع وفي الموسم الثاني عند معاملة النقع لمدة 12ساعة في حاصل البذور بلغ 3982.79 كغم/ هكتار بينما أعطى الصنف المحلي عند

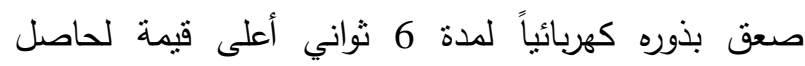

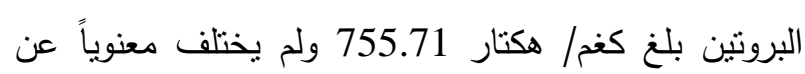

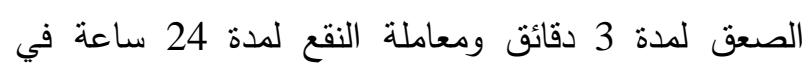
الموسم الثاني. نستتتج من الدراسة تفوق معاملة النقع بحامض النتروز المطفر لمدة 24 ساعة وتعد هذه الوسيلة كفوءه للحصول على تغايرات وراثية لأصناف الباقلاء لأجل

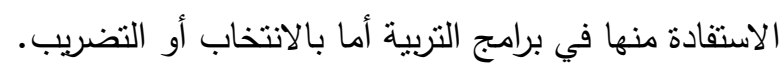

